\title{
MELATONIN CONCENTRATIONS AND SLEEP QUALITY IN PATIENTS WITH TYPE 2 DIABETES AND OBESITY
}

\author{
leva Kalere ${ }^{1, \#}$, Ilze Konrāde ${ }^{2}$, Anna Proskurina ${ }^{3}$, Sabīne Upmale ${ }^{2}$, Tatjana Zaḳe ${ }^{2}$, \\ Normunds Limba ${ }^{1}$, Gita Krievinaa ${ }^{1}$, Aivars Lejnieks ${ }^{2}$ and Pēteris Tretjakovs ${ }^{1,4}$ \\ ${ }^{1}$ Department of Human Physiology and Biochemistry, Rīga Stradiṇš University, 16 Dzirciema Str., Rīga, LV-1007, LATVIA \\ 2 Department of Internal Diseases, Rīga Stradiṇš University, 16 Dzirciema Str., Rīga, LV-1007, LATVIA \\ ${ }^{3}$ Pauls Stradiṇš Clinical University Hospital, 13 Pilsoṇu Str., Rīga, LV-1002, LATVIA \\ ${ }^{4}$ Institute of Cardiology and Regenerative Medicine, University of Latvia, 13 Pilsoṇu Str., Rīga, LV-1002, LATVIA \\ \# Corresponding author, ieva.kalere@gmail.com
}

Contributed by Aivars Lejnieks

There is a close relationship between melatonin as a circadian regulator and insulin, glucagon and somatostatin production. This study aimed to describe subgroups of type 2 diabetes mellitus (T2DM) patients that may benefit from melatonin clock-targeting properties. The study involved 38 participants: 26 T2DM patients, and 12 participants without diabetes in the control group. Subjects were asked to complete the questionnaire of Pittsburgh Sleep Quality Index (PSQI). Standard biochemical venous sample testing was performed, and a sample of saliva was collected for melatonin testing. Melatonin concentration in participants without obesity (body mass index $\left.(B M I)<30 \mathrm{~kg} / \mathrm{m}^{2}\right)$ was significantly higher than in obese participants: $13.2(6.4 ; 23.50) \mathrm{pg} / \mathrm{ml} \mathrm{vs}$ $5.9(0.78 ; 13.1) \mathrm{pg} / \mathrm{ml}, p=0.035$. Subjects with $B M I \geq 30 \mathrm{~kg} / \mathrm{m}^{2}$ had a significantly higher PSQI score than non-obese subjects: $7(4.5 ; 10)$ vs $5.5(3 ; 7), p=0.043$. T2DM patients showed significantly lower levels of melatonin than the control group: 6.1 (0.78; 12.2) $\mathrm{pg} / \mathrm{ml}$ vs 17.8 (8.2; 25.5) $\mathrm{pg} / \mathrm{ml}, p=0.003$. T2DM patients using short-acting insulin analogues showed a significantly higher PSQI score than patients not using insulin: $9(6 ; 10)$ vs $6(3 ; 8)$, respectively $(p=0.025)$. Poor sleep quality was more prevalent in patients with diabetic retinopathy than in those without this complication $(\mathrm{p}=0.031)$. Lower melatonin levels were detected in T2DM and obese patients. Furthermore, poor sleep quality was observed in T2DM patients using short-acting insulin analogues and those with diabetic retinopathy, and obese individuals.

Key words: melatonin, obesity, sleep quality, type 2 diabetes.

\section{INTRODUCTION}

Type 2 diabetes mellitus (T2DM) is a multifactorial illness with both genetic and environmental factors playing an important role in its pathogenesis. Along with traditional triggers such as an unhealthy diet and a sedentary lifestyle, a growing body of evidence suggests circadian rhythm disorders as a risk factor for diabetes. Results of previous human studies indicate that the circadian system plays a key role in the daily fluctuation of glucose tolerance, regardless of eating/fasting (la Fleur et al., 2001; Morris et al., 2015). There is strong evidence that circadian rhythm dysregulation, which in the modern world is increasingly caused by shift work, sleep and eating regimen, is associated with an in- creased risk of developing cardiovascular and metabolic diseases, including obesity and T2DM.

Circadian rhythm is the internal biological rhythm with a period of about 24 hours. The circadian rhythm system allows the body to synchronise behaviour and internal physiological and molecular processes with the changing environment, its 24-hour light/dark cycle. One of the main hormones in this regulation is melatonin synthesised in the epiphysis. The highest concentration is observed between $11 \mathrm{PM}$ and $3 \mathrm{AM}$, with a drastic decrease before dawn. It is important to note that melatonin does not regulate the sleep/wake cycle itself; its function is the initiation and maintenance of sleep. 
There is a close relationship between melatonin as a circadian regulator and insulin, glucagon and somatostatin production. Effects of melatonin are mediated through transmembrane melatonin (MT) 1 and MT2 receptors. Both isoforms are expressed in pancreatic Langerhans Island beta, alpha and delta cells (Mühlbauer and Peschke, 2007; Ramracheya, 2008). In a healthy human body, insulin levels are low at night and high during the day, corresponding to a high level of melatonin at night and low level during the light period of the day (Boden et al., 1996). It has been described that in Goto Kakizaki rats - the T2DM rodent model - melatonin levels and the arylalkylamine- $\mathrm{N}$-acetyltransferase (AA-NAT) activity (the central enzyme of the melatonin synthesis) in the epiphysis is reduced (Peschke et al., 2006; Frese et al., 2009). In contrast, type 1 diabetes mellitus models with streptozotocin-induced diabetes showed reduced insulin and elevated melatonin levels, as well as elevated pineal expression of AA-NAT mRNA (Peschke et al., 2008). These observations indicate functional antagonism between melatonin and insulin. Catecholamines should also be considered to be involved in melatonin-insulin interaction, particularly noradrenaline as the "launcher" of melatonin synthesis in the pineal gland.

Melatonin inhibits adenylate cyclase (cAMP) and guanylate cyclase (cGMP) cascades in the pancreatic $\beta$-cells, thereby reducing insulin secretion, but activates the phospholipase C/IP3 cascade by mobilising intracellular calcium reserves and consequently increasing insulin secretion (Peschke et al., 2002; Bach et al., 2005; Stumpf et al., 2009). Disrupted circadian rhythm of melatonin and desynchronisation of receptor signals may alter insulin secretion and glucose tolerance. There is also a hypothesis that the inhibitory effect of melatonin on $\beta$-cells and the observed antioxidant activity protects $\beta$-cells from functional overload, thus delaying the development of diabetes (Costes et al., 2015; Park et al., 2014).

Considering the above-mentioned effects, melatonin or melatonin receptor agonists are considered as a potentially chronotherapeutic drugs in the treatment of metabolic diseases (Forrestel et al., 2017). However, type 2 diabetic patients are a very heterogeneous group regarding metabolic compensation, insulin resistance, residual endogenous insulin secretion and therapeutic strategy, and further investigations are needed to find the subgroup that most benefits from melatonin clock-targeting properties.

\section{MATERIALS AND METHODS}

The study involved 38 participants: 26 type 2 diabetes patients, and 12 participants without diabetes in the control group. Twenty of the 38 study participants had obesity (19 of them also had T2DM, one was without T2DM). The study involved 20 women and 18 men aged 26 to 86 years. The patients were enrolled at Rīga East University Hospital Gailezers.
Ethical approval was obtained from Medical and Biomedical Research Ethics Committee of the Rìga East Clinical University Hospital's Support Foundation, and all participants signed an informed consent form prior to their study participation.

The doctors of the enrolled patients were asked to complete a questionnaire on their patients' diabetes and co-morbidity treatment. Each participant was asked to complete two questionnaires. The first questionnaire consisted of questions regarding history of diabetes and lifestyle factors: dietary, smoking, alcohol and caffeine-containing beverage intake habits. Each participant also completed the questionnaire of Pittsburgh Sleep Quality Index (PSQI). PSQI is an effective tool for assessing sleep quality in adults. The "good" and "poor" quality of sleep is determined by evaluating the seven components: subjective sleep quality, sleep latency, sleep duration, habitual sleep efficiency, sleep disturbances, use of sleeping medication, and daytime dysfunction. The component scores are summed to produce a global score (range 0 to 21). Higher scores indicate worse sleep quality. The score is calculated according to a formula (Buysse et al., 1989) where $\geq 5$ is 'poor' sleep quality.

Standard biochemical venous sample testing was performed (glycated haemoglobin $\mathrm{HbA1c}$, C-peptide, alanine aminotransferase, and creatinine, and glomerular filtration rate was calculated). In addition, one sample of unstimulated saliva was collected for melatonin testing immediately after awakening (6:00 to 6:30 AM). Sampling was done in fasted state (dietary restrictions - no chocolate, bananas, coloured drinks, tea, coffee, alcohol on the day of sampling). A sample was collected either by spitting into a laboratory tube or by buccal swab. Following sampling, the sample was refrigerated within 30 minutes, and frozen at $-20{ }^{\circ} \mathrm{C}$ within four hours. On the day of testing, the samples were defrozen and centrifuged at $1500 \times \mathrm{g}$ for 15 minutes, then the samples were added to an analyte plate within 30 minutes. Testing was performed with the Salimetrics ${ }^{\circledR}$ Melatonin Enzyme Immunoassay Kit in accordance with the manufacturer's instructions (Salimetrics: Melatonin ELISA Kit (Saliva) Salimetrics Assays, https://www.salimetrics.com/assaykit/melatonin-salivary-elisa-eia-kit). The data were processed and analysed using Microsoft Excel and IBM SPSS 20. Non-parametric statistical methods were employed. The results are shown as median (interquartile range). Continuous variable differences between the two groups were analysed with the Mann-Whitney test, and the Spearman's rank correlation coefficient was used for correlation testing. Relationship between two nominal (categorical) variables was calculated using the $\chi 2$ or Fisher test. A significance level $\alpha=0.05$ was used.

\section{RESULTS}

This study showed a trend of negative correlation of PSQI score with melatonin concentration: $\rho=-0.219, p=0.187$ (see Fig. 1). Twenty-five study participants $(65.8 \%)$ showed a PSQI score of $\geq 5: 18$ in the T2DM group and seven in the 


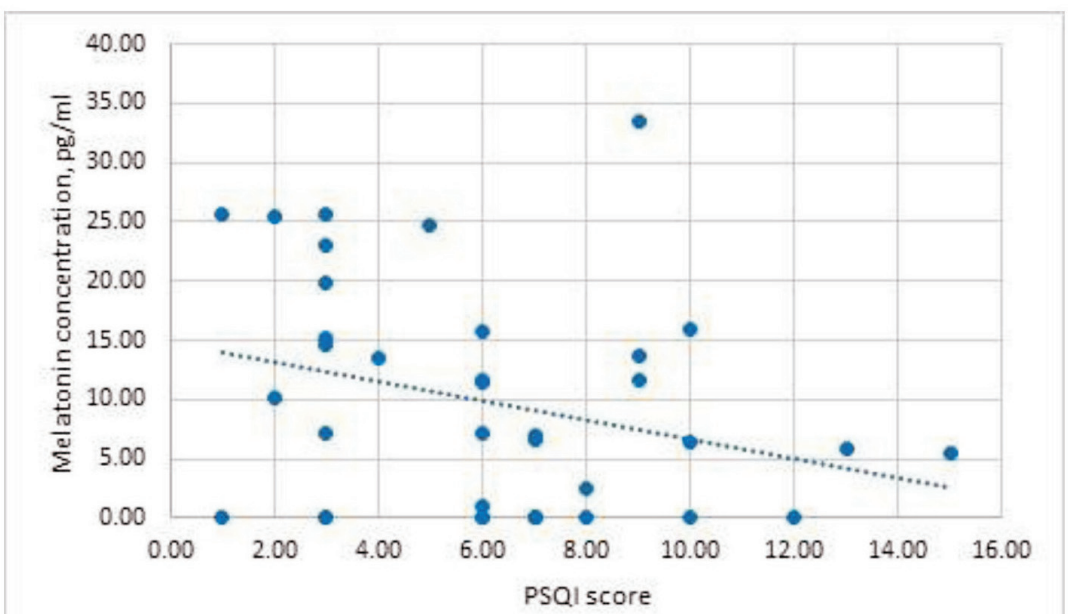

Fig. 1. Correlation of PSQI score and salivary concentration of melatonin. control group. Subjects with a PSQI score $\geq 5$ had a median melatonin concentration of $6.6(0.78 ; 12.7) \mathrm{pg} / \mathrm{ml}$ vs those with PSQI score $<5$ :14.6 (4.0; 24.3) pg/ml, $p=0.113$.

The overall BMI of the study population was 31.5 (26.0; $39.3) \mathrm{kg} / \mathrm{m}^{2}$. Patients with T2DM had a significantly higher BMI than the control group: $36.1(28.9 ; 40.5) \mathrm{kg} / \mathrm{m}^{2}$ vs 23.2 $(21.2 ; 27.0) \mathrm{kg} / \mathrm{m}^{2}$, respectively, $p<0.001$. Melatonin concentration in participants without obesity was significantly higher than in obese participants: $13.2(6.4 ; 23.50) \mathrm{pg} / \mathrm{ml}$ vs $5.9(0.78 ; 13.1) \mathrm{pg} / \mathrm{ml}, p=0.035$.

Obese participants had a significantly higher PSQI score than non-obese subjects: $7(4.5 ; 10)$ vs $5.5(3 ; 7), p=0.043$. PSQI score was correlated with height: $\rho=-0.405$, $p=0.012$, but not body weight $(p=0.894)$.

Regarding concentration of melatonin in T2DM patients and participants without T2DM, a significantly higher concentration was observed in the control group: 17.8 (8.2; $25.5) \mathrm{pg} / \mathrm{ml}$ vs $6.1(0.78 ; 12.2) \mathrm{pg} / \mathrm{ml}, p=0.003$. Patients with T2DM had a median PSQI score of $6.5(3.0 ; 9.3)$ vs $5.5(3.0 ; 7.0)$ in the control group, $p=0.303$.

No significant correlation was observed between glycated haemoglobin and melatonin concentration in the study group: $\rho=0.115, p=0.577$ (see Table 1). The HbA1c result was $>8 \%$ in 15 of the 26 T2DM patients with an available test result. The PSQI score was $\geq 5$ in $80 \%$ of T2DM patients with $\mathrm{HbA1c}>8 \%$ compared to $54.5 \%$ in T2DM patients with $\mathrm{HbA} 1 \mathrm{c} \leq 8 \%(p=0.218) .61 .5 \%$ of T2DM patients had T2DM duration $>10$ years. Patients with T2DM duration of $\leq 10$ years had melatonin concentration of 8.6 $(0.78 ; 17.8) \mathrm{pg} / \mathrm{ml}$, whereas patients with T2DM duration of $>10$ years: $5.6(0.78 ; 10.8) \mathrm{pg} / \mathrm{ml}, p=0.307$. The PSQI score was correlated significantly with T2DM duration: $\rho=0.663, p<0.001 .93 .8 \%$ of T2DM patients with diabetes duration of 10 years had a PSQI score of $\geq 5$, but this percentage was significantly lower in T2DM patients with shorter history of diabetes $-30 \%(p=0.001)$.

Oral antidiabetic drugs exclusively were used by $50.0 \%$ of T2DM patients $(n=13)$, insulin by $19.2 \%(n=5)$, and combined treatment with both oral antidiabetic drugs (OADs) and insulin by $30.8 \%(n=8)$ of the patients. Patients on OAD treatment exclusively showed melatonin concentration of $2.4(0.78 ; 13.3) \mathrm{pg} / \mathrm{ml}$, whereas those on insulin (either in combination with OADs or on insulin only): 6.3 $(0.78 ; 12.6) \mathrm{pg} / \mathrm{ml}, p=0.920$. Patients using insulin had a median PSQI score of $8(6 ; 10)$ vs those taking only oral antidiabetic drugs: $6(2.5 ; 7.5), p=0.032$. Further analysis on the patient group using insulin revealed no difference in PSQI score between intermediate/long-acting inulin analogue users $(\mathrm{n}=10)$ and T2DM patients not using insulin $(n=13)$. However, patients using short-acting insulin ana-

Table 1

MELATONIN CONCENTRATIONS AND THE PERCENTAGE OF PARTICIPANTS WITH POOR SLEEP QUALITY ACCORDING TO THE PSQI SCORE IN T2DM PATIENT SUBGROUPS

\begin{tabular}{|c|c|c|c|c|c|}
\hline & I parameters & $\begin{array}{l}\text { Melatonin concentration, } \\
\text { pg/ml (median, IQR) }\end{array}$ & $\begin{array}{l}p \text { value for the difference } \\
\text { between two independent } \\
\text { groups }\end{array}$ & $\begin{array}{l}\text { Patient percentage with } \\
\text { PSQI score } \geq 5, \%\end{array}$ & $\begin{array}{l}p \text { value for the difference } \\
\text { between two independent } \\
\text { groups }\end{array}$ \\
\hline \multirow[t]{2}{*}{$\mathrm{HbA} 1 \mathrm{c}$} & $\leq 8 \%(\mathrm{n}=11)$ & $4.0(0.78 ; 13.2)$ & 0.674 & 54.5 & 0.218 \\
\hline & $>8 \%(\mathrm{n}=15)$ & $6.1(1.0 ; 12.0)$ & & 80.0 & \\
\hline \multirow[t]{2}{*}{ Duration } & $\leq 10$ years $(\mathrm{n}=10)$ & $8.6(0.78 ; 17.8)$ & 0.307 & 30.0 & $0.001^{*}$ \\
\hline & $>10$ years $(n=16)$ & $5.6(0.78 ; 10.8)$ & & 93.8 & \\
\hline \multirow[t]{2}{*}{ Therapy } & Only OAD $(\mathrm{n}=13)$ & $2.4(0.78 ; 13.3)$ & 0.920 & 53.8 & 0.089 \\
\hline & Insulin $(\mathrm{n}=13)$ & $6.3(0.78 ; 12.6)$ & & 84.6 & \\
\hline
\end{tabular}

PSQI, Pittsburgh Sleep Quality Index; T2DM, type 2 diabetes mellitus; * $p \leq 0.001$ 
MELATONIN CONCENTRATIONS AND THE PERCENTAGE OF PARTICIPANTS WITH POOR SLEEP QUALITY ACCORDING TO THE PSQI SCORE IN T2DM PATIENTS WITH AND WITHOUT CHRONIC MICROVASCULAR COMPLICATIONS OF T2DM

\begin{tabular}{|c|c|c|c|c|c|}
\hline \multicolumn{2}{|c|}{ T2DM complications } & \multirow{2}{*}{$\begin{array}{c}\text { Melatonin concentration, } \\
\mathrm{pg} / \mathrm{ml}(\text { median, IQR) }\end{array}$} & \multirow{2}{*}{\begin{tabular}{|c|}
$\begin{array}{c}p \text { value for the difference } \\
\text { between two independent } \\
\text { groups }\end{array}$ \\
0.664
\end{tabular}} & \multirow{2}{*}{$\begin{array}{l}\text { Patient percentage with } \\
\text { PSQI score } \geq 5, \% \\
50.0\end{array}$} & \multirow{2}{*}{\begin{tabular}{|c}
$\begin{array}{c}p \text { value for the difference } \\
\text { between two independent } \\
\text { groups }\end{array}$ \\
0.330
\end{tabular}} \\
\hline Diabetic nephropathy & Yes $(n=6)$ & & & & \\
\hline & No $(n=20)$ & $3.4(0.78 ; 11.8)$ & & 75.0 & \\
\hline \multirow[t]{2}{*}{ Diabetic polyneuropathy } & Yes $(n=18)$ & $9.4(1.2 ; 13.1)$ & 0.427 & 72.2 & 0.667 \\
\hline & No $(n=8)$ & $5.6(0.78 ; 11.0)$ & & 62.5 & \\
\hline \multirow[t]{2}{*}{ Diabetic retinopathy } & Yes $(\mathrm{n}=8)$ & $7.2(0.78 ; 13.6)$ & 0.257 & 100.0 & 0.031 \\
\hline & No $(n=18)$ & $3.3(0.78 ; 8.0)$ & & 55.6 & \\
\hline
\end{tabular}

PSQI, Pittsburgh Sleep Quality Index; T2DM, type 2 diabetes mellitus

logues $(n=11)$ showed a significantly higher PSQI score than T2DM patients not using insulin: $9(6 ; 10)$ vs $6(3 ; 8)$, respectively $(p=0.025)$.

T2DM patients with microvascular complications had insignificantly lower melatonin levels than those without respective complications. In patients with chronic microvascular complications of T2DM, a significant difference was found in the case of diabetic retinopathy (see Table 2).

\section{DISCUSSION}

The current study evaluated melatonin levels and sleep quality in T2DM and obese patients. We showed that both T2DM and obesity were associated with lower melatonin levels. Furthermore, obesity was also associated with poor sleep quality according to the PSQI score.

Sleep disorders in patients with morbid obesity have been described in detail in another review (Akinnusi et al., 2012). Such disorders include obstructive sleep apnea, obesity hypoventilation syndrome and central sleep apnea, excessive daytime sleepiness, narcolepsy and night eating syndrome. Obstructive sleep apnea has been shown to be associated with insulin resistance as evidenced by higher fasting insulin concentration and HOMA-IR in subjects experiencing apnea/hypopnea episodes (Ip et al., 2002). In addition, it has been reported that $50 \%$ of adult diabetic patients suffer from insomnia (Skomro et al., 2001) and have lower night-time melatonin levels. In fact, data show that metformin is associated with enhanced sleep efficiency in patients with T2DM. A reduced level of night-time melatonin has been found to be associated with increased risk of T2DM, as melatonin affects insulin secretion, hepatic glucose metabolism and insulin sensitivity (Andrew et al., 2017).

Unlike the current study, previous studies have reported a significant association of poor sleep quality and lower metabolic control of T2DM. In a study involving elderly T2DM patients it was found that higher PSQI scores (i.e., worse sleep quality) were associated with various factors including higher HbA1c and insulin application (Jin et al., 2012). Likewise, an association of impaired night-time sleep qual- ity, excessive daytime sleepiness and reduced self-management in adults with T2DM was detected (Chasens et al, 2013). Our study also suggests poor sleep quality in the subgroup of T2DM patients using short-acting insulin analogues.

Deterioration of circadian changes in melatonin secretion in patients with T2DM has been previously reported (Tutuncu et al., 2005). That study described associations with diabetic neuropathy, but did not find significant changes regarding other chronic complications of T2DM, e.g., diabetic retinopathy.

Nevertheless, other studies have described altered melatonin production in diabetic patients with proliferative diabetic retinopathy. These studies found lower levels of melatonin (Hikichi et al., 2011) or its metabolites (Chen et al., 2014) in cases of diabetic retinopathy. It is suggested that advanced dysfunction of retinal light perception may cause altered melatonin secretion (Hikichi et al., 2011), furthermore not only diabetic retinopathy but also panretinal photocoagulation might be associated with reduced retinal light perception. On the other hand, lower melatonin levels may be a part of proliferative diabetic retinopathy pathogenesis. (Chen et al., 2014). The present study reports altered sleep quality among patients with diabetic retinopathy.

Melatonin has been shown to have an antioxidant effect (Bonnefont-Rousselot et al., 2011), which may be a protective factor in the pathogenesis of diabetes and diabetic retinopathy. According to multiple studies, melatonin has several beneficial effects, such as beta cell protection, obesity prevention, serum glucose and triacylglycerol reduction, and insulin sensitising properties (Forrestel et al., 2017). Whether melatonin is a feasible option for glucose control remains a subject of debate. Firstly, the effective dose is higher than the treatment dose for sleep disorders. To add to that, studies have found that acute exposure to melatonin can decrease insulin secretion and impair glucose tolerance in carriers of MTNR1B risk G allele (Mulder, 2017). On the contrary, melatonin improves fasting and postprandial glycemic control and HbAlc levels when combined with oral 
glucose lowering agents (Mulder, 2017; Forrestel et al., 2017).

Further studies would be necessary to fully evaluate the association between various subgroups of T2DM patients, melatonin levels and sleep quality, and the possibility of melatonin use in patients with diabetes and its complications.

Limitations of the current study include the rather low number of participants. This may contribute to higher $p$ values and therefore insignificant differences between groups.

\section{CONCLUSIONS}

Our results showed that patients with T2DM and obesity have lower melatonin levels. Furthermore, poor sleep quality was observed in T2DM patients using short-acting insulin analogues and those with diabetic retinopathy, and obese individuals. We suggest that the above-mentioned subgroups of T2DM patients might most benefit from melatonin clock-targeting properties but further studies would be necessary to fully evaluate the association between various subgroups of T2DM patients, melatonin levels and sleep quality, and the possibility of melatonin use in patients with diabetes and its complications.

\section{ACKNOWLEDGEMENTS}

The publication was supported in part by grant No. 2014.10-4/VPP-1.1.2 and -5.1.2 in the framework of the Latvian National Programme.

\section{REFERENCES}

Akinnusi, M. E., Saliba, R., Porhomayon, J., El-Solh, A. A. (2012). Sleep disorders in morbid obesity. Euro. J. Int. Med., 23 (3), 219-226.

Bach, A. G., Wolgast, S., Muhlbauer, E., Peschke, E. (2005). Melatonin stimulates inositol-1,4,5-trisphosphate and $\mathrm{Ca} 2+$ release from INS1 insulinoma cells. J. Pineal Res., 39 (3), 316-323.

Boden, G., Ruiz, J., Urbain, J. L., Chen, X. (1996). Evidence for a circadian rhythm of insulin secretion. Amer. J. Physiol., 271 (2), 246-252.

Bonnefont-Rousselot, D., Collin, F., Jore, D., Gardès-Albert, M. (2011). Reaction mechanism of melatonin oxidation by reactive oxygen species in vitro. J. Pineal Res., 50 (3), 328-335.

Buysse, D. J., Reynolds, C. F. 3rd, Monk, T. H., Berman, S. R., Kupfer, D. J. (1989). The Pittsburgh Sleep Quality Index: A new instrument for psychiatric practice and research. Psych. Res., 28 (2), 193-213.

Chasens, E. R., Korytkowski, M., Sereika, S. M., Burke, L. E. (2013). Effect of poor sleep quality and excessive daytime sleepiness on factors associated with diabetes self-management. The Diabetes Educator, 39 (1), $74-82$.

Chen, W., Cao, H., Lu, Q. Y., Wang, N., Zhao, S. Z., Xu, X., Zheng, Z. (2014). Urinary 6-sulfatoxymelatonin level in diabetic retinopathy patients with type 2 diabetes. Int. J. Clin. Exper. Pathol., 7 (7), 4317-4322.
Costes, S., Boss, M., Thomas, A. P., Matveyenko, A. V. (2015). Activation of melatonin signaling promotes $\beta$-cell survival and function. Mol. Endocrinol., 29 (5), 682-692.

Forrestel, A. C., Miedlich, S. U., Yurcheshen, M., Wittlin, S. D., Sellix, M. T. (2017). Chronomedicine and type 2 diabetes: Shining some light on melatonin. Diabetologia, 60 (5), 808-822.

Frese, T., Bach, A. G., Mühlbauer, E., Pönicke, K., Brömme, H. J., Welp, A., Peschke, E. (2009). Pineal melatonin synthesis is decreased in type 2 diabetic Goto-Kakizaki rats. Life Sciences, 85 (13-14), 526-533.

Hikichi, T., Tateda, N., Miura, T. (2011). Alteration of melatonin secretion in patients with type 2 diabetes and proliferative diabetic retinopathy. Clin. Ophthalmol., 5, 655-660.

Ip, M. S., Lam, B., Ng, M. M., Lam, W. K., Tsang, K. W., Lam, K. S. (2002) Obstructive sleep apnea is independently associated with insulin resistance. (2002). Amer. J. Respir. Crit. Care Med., 165 (5), 670-676.

Jin, Q. H., Chen, H. H., Yu, H. L., Li, T. L. (2012). The relationship between sleep quality and glucose level, diabetic complications in elderly type 2 diabetes mellitus. Zhonghua Nei Ke Za Zhi, 51 (5), 357-361.

la Fleur, S. E., Kalsbeek, A., Wortel, J., Fekkes, M. L., Buijs, R. M. (2001). A daily rhythm in glucose tolerance: A role for the suprachiasmatic nucleus. Diabetes, 50 (6), 1237-1243.

Morris, C. J., Yang, J. N., Garcia, J. I., Myers, S., Bozzi, I., Wang, W., Buxton, O., M., A. Shea, S., A., Scheer, F., A., J., L. (2015). Endogenous circadian system and circadian misalignment impact glucose tolerance via separate mechanisms in humans. Proc. Nat. Acad. Sci., 112 (17), 2225-2234.

Mulder, H. (2017). Melatonin signaling and type 2 diabetes risk: Too little, too much or just right? Diabetologia, 60, 826-829.

Mühlbauer, E., Peschke, E. (2007). Evidence for the expression of both the MT1- and in addition, the MT2-melatonin receptor, in the rat pancreas, islet and beta-cell. J. Pineal Res., 42 (1), 105-106.

Park, J. H., Shim, H. M., Na, A. Y., Bae, K. C., Bae, J. H., Im, S. S., Cho, H. C., Song, D. K. (2014). Melatonin prevents pancreatic $\beta$-cell loss due to glucotoxicity: The relationship between oxidative stress and endoplasmic reticulum stress. J. Pineal Res., 56 (2), 143-153.

Peschke, E., Frese, T., Chankiewitz, E., Peschke, D., Preiss, U., Schneyer, U., Spessert, R., Mühlbauer, E. (2006). Diabetic Goto Kakizaki rats as well as type 2 diabetic patients show a decreased diurnal serum melatonin level and an increased pancreatic melatonin-receptor status. J. Pineal Res., 40 (2), 135-143.

Peschke, E., Mühlbauer, E., Musshoff, U., Csernus, V. J., Chankiewitz, E., Peschke, D. (2002). Receptor (MT(1)) mediated influence of melatonin on cAMP concentration and insulin secretion of rat insulinoma cells INS-1. $J$. Pineal Res., 33 (2), 63-71.

Peschke, E., Wolgast, S., Bazwinsky, I., Ponicke, K., Muhlbauer, E. (2008). Increased melatonin synthesis in pineal glands of rats in streptozotocin induced type 1 diabetes. J. Pineal Res., 45 (4), 439-448.

Ramracheya, R. D., Muller, D. S., Squires, P. E., Brereton, H., Sugden, D. Huang, G. C., Amiel, S. A., Jones, P. M., Persaud, S. J. (2008). Function and expression of melatonin receptors on human pancreatic islets. J. Pineal Res., 44 (3), 273-279.

Skomro, R. P., Ludwig, S., Salamon, E., Kryger, M. H. (2001). Sleep complaints and restless legs syndrome in adult type 2 diabetics. Sleep Med., 2, $417-422$.

Stumpf, I., Bazwinsky, I., Peschke, E. (2009). Modulation of the cGMP signaling pathway by melatonin in pancreatic beta-cells. J. Pineal Res., 46 (2), 140-147.

Tutuncu, N. B., Batur, M. K., Yildirir, A., Tutuncu, T., Deger, A., Koray, Z., Erbas, B., Kabakci, G., Aksoyek, S., Erbas, T. (2005). Melatonin levels decrease in type 2 diabetic patients with cardiac autonomic neuropathy. $J$. Pineal Res., 39 (1), 43-49. 


\section{MELATONĪNA KONCENTRĀCIJA UN MIEGA KVALITĀTE 2. TIPA CUKURA DIABĒTA PACIENTIEM UN PACIENTIEM AR APTAUKOŠANOS}

Endogēnie cirkadiānie ritmi cieši saista melatonīna un insulīna, glikagona kā arī somatostatīna izdali. Pētījuma mērkị bija noteikt 2. tipa cukura diabēta (2TCD) pacientu apkašgrupas, kurām būtu ieguvums no melatonīna diennakts ritma regulējošā efekta. Pētījumā tika iekḷauti 38 dalībnieki. No tiem 26 bija 2TCD pacienti (analizētas apakšgrupas atbilstoši 2TCD kompensācijai (HbA1c), slimības ilgumam, lietotajai terapijai, esošajām mikrovaskulārajām komplikācijām) un 12 dalībnieki bez cukura diabēta kontroles grupā. No 38 pētījuma dalībniekiem 20 bija ar aptaukošanos (19 no tiem 2TCD pacienti, viens dalībnieks bez 2TCD). Dalībniekiem bija jāaizpilda miega kvalitātes anketa Pitsburgh Sleep Quality Index (PSQI), kur rezultāts $\geq 5$ nozīmē sliktu miega kvalitāti. Tika analizēti venozo asiṇu paraugi bioḳimisko rādītāju un siekalu paraugs melatonīna koncentrācijas noteikšanai. Melatonīna koncentrācija bija statistiski ticami augstāka pacientiem bez aptaukošanās (ḳermena masas indekss $\left.(\mathrm{KMI})<30 \mathrm{~kg} / \mathrm{m}^{2}\right)$, salīdzinot ar pacientiem ar aptaukošanos: 13,2 $(6,4 ; 23,5) \mathrm{pg} / \mathrm{ml} \mathrm{un} 5,9(0,7$; $13,1) \mathrm{pg} / \mathrm{ml}, p=0,035$. Dalībniekiem ar K̦MI $\geq 30 \mathrm{~kg} / \mathrm{m}^{2}$ bija augstāks PSQI rezultāts nekā pacientiem bez aptaukošanās: 7,0 (4,5; 10,0) un $5,5(3,0 ; 7,0), p=0,043$. 2TCD pacientiem bija izteikti zemāks melatonīna līmenis nekā kontroles grupā: $6,1(0,7 ; 12,2) \mathrm{pg} / \mathrm{ml}$ un attiecīgi $17,8(8,2 ; 25,5) \mathrm{pg} / \mathrm{ml}, p=0,003$. 2TCD pacientiem, kuri terapijā saņem īsas darbības insulīna analogus, bija augstāks PSQI rezultāts nekā pacientiem bez insulīna terapijas: $9,0(6,0 ; 10,0)$ un $6,0(3,0 ; 8,0)(p=0,025)$. Tika novērota sliktāka miega kvalitāte pacientiem ar diabētisku retinopātiju, salīdzinājumā ar pacientiem bez šīs komplikācijas $(p=0,031)$. Zemāks melatonīna līmenis tika konstatēts pacientiem ar 2TCD un pacientiem ar aptaukošanos. Sliktāka miega kvalitāte tika novērota 2TCD pacientiem, kuri terapijā saņēma îsas darbības insulīna analogus un kuriem ir diabētiska retinopātija, kā arī pacientiem ar aptaukošanos. 